\title{
KEDUDUKAN ANAK ADOPSI MENURUT KITAB UNDANG-UNDANG HUKUM PERDATA
}

\section{POSITION OF ADOPTED CHILDREN ACCORDING TO THE BOOK CIVIL LAW}

\author{
Riza Yudha Patria \\ Fakultas Hukum Universitas Tulang Bawang Lampung \\ Rizayudhap12@gmail.com
}

\begin{abstract}
Abstrak
Anak dimaknai sebagai karunia Tuhan untuk membahagiakan dan memperkokoh ikatan cinta kasih sepasang suami dan istri. Kenyataanya, ada pasangan suami isteri yang tidak mempunyai anak keturunan yang didambakan, dengan berbagai sebab, mulai dari sebab yang bersifat medis sampai faktor keturunan. Pasangan suami isteri akan berusaha menghadirkan anak ditengah kehidupan rumah tangganya, dengan jalan adopsi anak. Permasalahan dalam penulisan ini adalah syarat-syarat untuk mengadopsi anak dan status anak adopsi menurut hukum perdata. Tujuan penelitian ini adalah untuk mengetahui bagaimana proses pengajuan adopsi anak. Metode pendekatan yang di gunakan dalam penelitian ini adalah pendekatan perundang-undangan. Metode penyajian data dalam penelitian dilakukan secara deskriptif. Analisis yang di pergunakan dalam penulisan ini adalah konseptual. Hasil penelitian menunjukan bahwa syarat-syarat untuk mengadakan adopsi anak dapat dilakukan sesuai dengan Surat Edaran Mahkamah Agung RI NO.6/83 yang mengatur tentang cara mengadopsi anak menyatakan bahwa untuk mengadopsi anak harus terlebih dahulu mengajukan permohonan.
\end{abstract}

Kata Kunci : Hukum Perdata, Adopsi, Anak

\begin{abstract}
Absract
Children are interpreted as a gift from God to make them happy and strengthen the bond of love between a husband and wife. In fact, there are married couples who do not have the desired offspring, for various reasons, ranging from medical causes to hereditary factors. Married couples will try to bring children in the middle of their domestic life, by adopting children. The problem in this paper is the requirements for adopting a child and the status of an adopted child according to civil law. The purpose of this study was to find out how the process of applying for child adoption. The approach method used in this research is the statutory approach. The method of presenting data in this research is done descriptively. The analysis used in this paper is conceptual. The results of the study indicate that the conditions for adopting a child can be carried out in accordance with the Circular Letter of the Supreme Court of the Republic of Indonesia NO. 6/83 which regulates how to adopt a child stating that to adopt a child, you must first submit an application.
\end{abstract}

Keywords: Civil law, Adoption, Child 


\section{A. Pendahuluan}

Salah satu hikmah dan tujuan perkawinan adalah untuk memperoleh anak. Anak sering dimaknai sebagai karunia Tuhan untuk membahagiakan dan memperkokoh ikatan cinta kasih sepasang suami dan istri.

Anak juga merupakan amanat Tuhan kepada ayah dan ibu agar dipersiapkan sebagai hamba untuk mengabdi kepadaNya dan sekaligus menjadi khalifahNya untuk memakmurkan bumi. Namun pada kenyataanya, ada pasangan suami isteri yang tidak mempunyai anak keturunan yang didambakan, dengan berbagai sebab, mulai dari sebab yang bersifat medis sampai faktor keturunan.

Maka pasangan suami isteri akan berusaha untuk menghadirkan anak ditengah kehidupan rumah tangganya, dengan jalan menjadikan anak orang lain sebagai anak angkatnya. Pada sisi lain, ada anak yang seharusnya memperoleh hak- haknya sebagai anak seperti kasih sayang, pendidikan dan nafkah tetapi tidak mendapatkanya. Tidak sedikit orang tua yang seharusnya bertanggung jawab untuk memenuhi hak-hak anak telah dilahirkan mereka, akan tetapi karena antara lain keterbatasan ekonomi orang tua anak atau salah satu atau kedua orang tua anak sudah tidak ada lagi, sehingga mereka tidak bisa memenuhi tanggung jawabnya itu. kondisi sosial anak yang demikian sering menimbulkan kepedulian sosial pada pasangan suami isteri untuk menjadikan mereka sebagai anaknya.

Adopsi adalah pengangkatan anak oleh seseorang dengan maksud untuk menganggap anak itu sebagai anaknya sendiri. Tindakan pengangkatan anak ini tidak menimbulkan terputusnya hubungan darah antara si anak dan orang tua kandungnya sendiri. Tujuan terbesar dalam pengangkatan anak adalah untuk semata-mata meningkatkan kesejahteraan anak adopsi itu sendiri terutama dalam kedudukanya.

Adopsi anak rentan sekali memunculkan permasalahan dalam keluarga baik keluarga kandung maupun keluarga angkat dan yang paling utama adalah bagi diri anak adopsi itu sendiri. Mengadopsi anak itu bukan keputusan yang mudah, sebab yang harus dipikirkan pasangan yang akan mengadopsi anak adalah pandangan jauh ke depan, ke 15 sampai 20 tahun yang akan datang.

Anak adopsi berbeda dengan anak kandung, karena suatu ketika anak adopsi akan mengetahui dengan kenyataan bahwa dirinya ternyata hanyalah seorang anak adopsi. Konflik yang dirasakanya adalah, mengapa 
dirinya diberikan pada orang lain pada umumnya anak adopsi tidak pernah bisa mengerti alasan apapun yang membuat dirinya diberikan pada orang lain. Bila anak sudah diliputi oleh perasaan demikian, maka tiba-tiba dirinya akan merasa menjadi individu yang tanpa identitas.

Anak adopsi akan mengalami krisis identitas, padahal identitas diperlukan manusia dalam mengembangkan sikap dan prilaku untuk penyesuaian diri. Akibatnya anak yang dalam kondisi demikian akan mengalami gangguan sulit menyesuaiakan diri beradaptasi. berekspresi atau memiliki gangguan emosional. Bila hal ini terjadi, baik buruk nasibnya hanya tergantung pada sikap orang tua dan saudara- saudara angkatnya. Bila mendukung, maka anak adopsi bisa diselamatkan, namun bila sebaliknya maka anak adopsi akan makin terperosok.

Hal-hal tersebut di atas bila terjadi akan menimbulkan permasalahan yang lebih rumit lagi, sebab adopsi yang telah dilakukan tidak mudah untuk dibatalkan. Akibat pengaruh praktek adopsi berdasarkan budaya yang memang dilakukan tanpa mengikuti prosedur hukum yang telah ditetapkan dalam perundang-undangan negara. Yang menjadi kendala saat ini adalah peraturan mengenai pengangkatan anak belum sepenuhnya tersosialisasi dengan baik, hal tersebut terbukti dengan adanya banyak kasus pengadopsian anak yang tidak melalui prosedur yang telah ditetapkan. untuk itulah diperlukan penanganan yang lebih serius mengenai pengangkatan anak dengan memberikan pemahaman yang benar kepada masyarakat mengenai prosedur pengangkatan anak adopsi.

\section{B. Metode Penelitian}

Metode penelitian yang digunakan adalah yuridis normatif dengan pendekatan perundang-undangan. Norma hukum menjadi dasar analisis untuk menjawab permasalahan penelitian. Metode penyajian data dalam penelitian dilakukan secara deskriptif. Analisis yang di pergunakan dalam penulisan ini adalah konseptual.

\section{Pembahasan}

\section{Pengertian Anak Adopsi}

Secara etimologi Adopsi berasal dari 'kata adoptie' bahasa belanda, 'atau adoption' bahasa inggris, yang berarti pengangkatan anak, atau mengangkat anak. Pengertian dalam bahasa Belanda menurut Kamus Hukum, berarti 'pengangkatan seorang anak untuk sebagai anak kandungnya sendiri.pengangkatan anak adalah suatu perbuatan hukum yang mengalihkan 
seorang anak dari lingkungan kekuasaan orangtua wali yang sah atau orang lain yang bertanggung jawab atas perawatan, pendidikan, dan membesarkan anak tersebut ke dalam lingkungan keluarga anak angkat. Bagaimanapun juga lembaga adopsi akan terus mengikuti perkembangan masyarakat yang terus beranjak kearah kemajuan dan merupakan suatu tuntutan terhadap KUHPerdata yang tidak mengatur masalah adopsi.

Untuk memenuhi tuntutan masyarakat tersebut, Masyarakat Belanda tahun 1917 mengeluarkan Staatsblad Nomor 129 Pasal 5 sampai 15 yang khususnya mengatur masalah adopsi atau anak angkat bagi golongan masyarakat Tionghoa. Karena Staatsblad No.29 tahun 1917 ini merupakan satu- satunya pelengkap dari KUHPerdata yang ada, maka untuk memasalahkan adopsi menurut versi Perdata semata-mata harus beranjak dari aturan Staatsblad ini.

\section{Dasar Hukum Anak Adopsi}

Adapun dasar-dasar hukum pengangkatan anak adopsi di Indonesia adalah sebagai berikut:

a) Staatsblad 1917, Pasal, 5 sampai dengan 15 mengatur masalah adopsi yang merupakan kelengkapan dari kitab undang-undang hukum
perdata/Burgerlijk wetboek yang ada.

b) Surat Edaran Mahkamah Agung RI Nomor 2 Tahun

c) Undang-Undang Nomor Tahun 1979 Tentang Kesejahteraan Anak.

d) Undang-Undang Nomor 6 Tahun 1974 Tentang Ketentuan-Ketentuan Pokok Kesejahteraan Sosial. ${ }^{1}$

\section{Alasan Dan Tujuan Pengangkatan}

\section{Anak Adopsi.}

Ada berbagai motivasi yang mendorong orang, mengangkat anak bahkan tidak jarang pula karena faktor sosial, ekonomi, budaya, maupun politik. antara lain sebagai berikut:

a) Keinginan mempunyai keturunan atau anak.

b) Keinginan untuk mendapatkan teman bagi dirinya sendiri atau anaknya.

c) Kemauan untuk menyalurkan rasa belas kasihan terhadap anak orang lain yang membutuhkan.

d) Adanya ketentuan hukum yang memberikan peluang untuk melakukan sesuatu pengangkatan anak.
${ }^{1}$ Rosnidar Sembiring, HukumKeluarga, Jakarta:
Sinar Grafika,1992, hlm. 161. 


\section{Syarat-Syarat Adopsi}

Surat Edaran Mahkamah Agung RI NO.6/83 yang mengatur tentang cara mengadopsi anak menyatakan bahwa untuk mengadopsi anak harus terlebih dahulu mengajukan permohonan Berdasarkan pasal 8 Staatsblad 1917 No.129 berkaitan dengan syarat-syarat tentang adopsi yaitu sebagai berikut:

a) Persetujuan orang yang mengangkat anak adopsi.

b) Apabila anak yang diangkat itu adalah anak sah dari orangtuanya itu, apabila bapak sudah wafat dan ibu telah kawin lagi, maka harus ada persetujuan dari walinya dan Balai Harta Peninggalan selaku pengawas wali.

c) Apabila anak yang akan diangkat itu adalah lahir diluar perkawinan, maka diperlukan izin dari orangtuanya, yang mengakuinya sebagai anak dan jika anak itu sama sekali tidak diakui sebagai anak, maka harus ada persetujuan dari walinya serta dari Balai Harta Peninggalan. $^{2}$

\section{Hak-hak dan Kewajiban Anak Adopsi}

Tujuan diadakanya perlindungan anak di Indonesia termasuk anak adopsi

\footnotetext{
${ }^{2}$ Soedaryo Soimin, Hukum Orang dan Keluarga, Jakarta: Sinar Grafika, 1992, hlm. 39.
}

adalah untuk menjamin terpenuhinya hak-hak anak agar tetap hidup, tumbuh, berkembang dan berpartisipasi secara optimal sesuai harkat dan martabat kemanusiaan, serta mendapat perlindungan dari kekerasan dan diskriminasi, demi terwujudnya anak indonesia yang berkualitas, berakhlak mulia dan sejahtera.

Anak adopsi dan anak-anak lain pada umunya merupakan amanah dari Tuhan Yang Maha Esa, yang didalamnya melekat hak-hak sebagai anak dan harkat serta martabat sebagai manusia seutuhnya yang perlu dihormati dan dijunjung tinggi oleh orang tua angkatnya dan masyarakat pada umumnya.

Undang-Undang Nomor 4 Tahun 1979 Bab II Pasal 1979 sampai dengan Pasal 9 mengatur hak-hak atas kesejahteraan sebagai berikut:

Pasal 2

1) Anak berhak atas kesejahteraan, perawatan, asuhan dan bimbingan berdasarkan kasih sayang baik dalam keluarganya maupun didalam asuhan khusus untuk tumbuh dan berkembang dengan wajar.

2) Anak berhak atas pelayanan untuk mengembangkan kemampuan dan kehidupan sosialnya, sesuai dengan kebudayaan dan kepribadian bangsa, untuk menjadi 
warganegara yang baik dan berguna.

3) Anak berhak atas pemeliharaan dan perlindungan, baik semasa dalam kandungan maupun sesudah dilahirkan.

4) Anak berhak atas perlindungan terhadap lingkungan hidup yang dapat membahayakan atau menghambat pertumbuhan dan perkembanganya dengan wajar

\section{Pasal 3}

Dalam keadaan yang membahayakan, anaklah yang pertama-tama berhak mendapat pertolongan, bantuan dan perlindungan.

Pasal 4

1) Anak yang tidak mempunyai orangtua berhak memperoleh asuhan oleh negara atau orang atau badan.

2) Pelaksanaan ketentuan ayat 1 diatur lebih lanjut dengan peraturan pemerintah.

\section{Pasal 5}

1) Anak yang tidak mampu berhak memperoleh bantuan agar dalam lingkungan keluarganya dapat tumbuh dan berkembang dengan wajar.
2) Pelaksanaan ketentuan ayat 1 diatur lebih lanjut dengan peraturan pemerintah. ${ }^{3}$

Pasal 6

1) Anak yang mengalami masalah kelakuan diberi pelayanan dan asuhan yang bertujuan menolongnya guna mengatasi hambatan yang terjadi dalam masa pertumbuhan dan perkembanganya.

2) Pelayanan dan asuhan, sebagaimana dimaksudkan dalam ayat 1, juga diberikan kepada anak yang telah dinyatakan bersalah melakukan pelanggaran hukum berdasarkan keputusan hakim.

3) hambatan yang terjadi dalam masa pertumbuhan dan perkembanganya.

4) Pelayanan dan asuhan, sebagaimana dimaksudkan dalam ayat 1, juga diberikan kepada anak yang telah dinyatakan bersalah melakukan pelanggaran hukum berdasarkan keputusan hakim.

Disamping hak-hak yang telah dijamin dan undang-undang tersebut, anak-anak atau termasuk anak angkat

\footnotetext{
${ }^{3}$ Fauzan, Akhmad Kamil, Hukum Perlindungan dan Pengangkatan Anak di Indonesia, Jakarta, PT Raja Grafindo Persada, 2008, hlm. 71.
} 
memilki kewajiban- kewajiban sebagai kewajiban asasi yang juga harus dilaksanakan oleh seorang anak, yaitu bahwa setiap anak berkewajiban untuk:

a. Menghormati orang tua, wali dan guru

b. Mencintai keluarga, masyarakat, dan menyayangi teman.

c. Mencintai tanah air, bangsa dan negara

\section{Pasal 7}

Anak cacat berhak memperoleh pelayanan khusus untuk mencapai tingkat pertumbuhan dan perkembangan sejauh batas kemampuan dan kesanggupan anak yang bersangkutan.

Pasal 8

Bantuan dan pelayanan, yang bertujuan mewujudkan kesejahteraan anak menjadi hak setiap anak tanpa membeda-bedakan jenis kelamin, agama, pendirian politik, dan kedudukan sosial. $^{4}$

\section{Tata Cara Pengangkatan Anak}

\section{Adopsi menurut Hukum Perdata}

Berikut dapat dijelaskan tata cara pengangkatan anak, dari mulai proses pengajuan hingga penetapan Pengadilan Negeri.

1) Tahap menyiapkan dokumen

Dokumen pribadi bersama pasangan seperti KTP, Kartu Keluarga, dan

\footnotetext{
${ }^{4}$ Undang-Undang Republik Indonesia No.4 Tahun 1979 Tentang Kesejahteraan Anak.
}

surat nikah atau akta nikah, selain untuk mendata identitas Calon Orang Tua Angkat, ini juga berfungsi untuk membuktikan bahwa pasangan suami isteri tersebut sah secara hukum sebagai pasangan dibuktikan dengan surat nikah yang valid.

Disamping hak-hak yang telah dijamin dan undang-undang tersebut, anak-anak atau termasuk anak angkat memilki kewajibankewajiban sebagai kewajiban asasi yang juga harus dilaksanakan oleh seorang anak, yaitu bahwa setiap anak berkewajiban untuk.
a. Menghormati orang tua, wali dan guru
b. Mencintai keluarga, masyarakat, dan menyayangi teman.

\section{Kedudukan Anak Menurut KUHPerdata}

Ada beberapa Status Anak Dalam Kitab Undang-Undang Hukum Perdata (Burgerlijk Wetboek) yang menggolongkan tiga penggolongan terhadap status anak, yaitu :

a) Anak sah, yaitu mereka yang lahir didalam suatu perkawinan, pengertian ini berdasarkan pasal 250 KUHPerdata, yakni: "Tiap- tiap anak yang dilahirkan atau 
ditumbuhkan sepanjang perkawinan, memperoleh si suami sebagai bapaknya".

b) Anak yang lahir diluar perkawinan, akan tetapi diakui oleh seorang ayah saja atau seorang ibu atau diakui oleh ayah dan ibu keduanya. Dalam hal ini ditegaskan dalam Pasal 272 KUHPerdata, yakni: kecuali anakanak yang dibenihkan dalam zina atau dalam sumbang, tiap-tiap anak yang terbuahkan diluar perkawinan, dengan kemudian bapak dan ibunya akan menjadi sah, Undang-undang atau apabila pengakuan itu dilakukan dalam akta perkawinan sendiri. Pengakuan anak menimbulkan pertalian kekeluargaan antara yang mengakui dengan yang diakui. Maksudnya apabila mengakui adalah ayah/ibu maka pertalian darah tersebut hanya dengan ayah, adapun yang lain tidak terkait dalam oleh pengakuan orang lain.

Demikian pula, apabila pengakuan tersebut dari pihak ibu, maka dalam hal ini timbul pertalian kekeluargaan dengan itu, akan tetapi tidak berlaku demikian bagi keluarga yang lain. seorang anak yang lahir diluar perkawinan kemudian menjadi anak sah apabila ayah dan ibu melakukan perkawinan secara sah. Anak yang menurut hukum tidak mempunyai ayah dan tidak punya ibu, hal ini terjadi pada anak diluar perkawinan, dan tidak diakui oleh kedua orangtuanya. ${ }^{5}$ Selain itu menurut Undang-Undang Nomor 1 Tahun 1974, Pasal 42-44 ketentuan Undang- Undang perkawinan kedudukan anak diatur secara tegas sebagai berikut :

Pasal 42 :

Anak sah adalah anak yang dilahirkan dalam atau sebagai akibat perkawinan yang sah.

Pasal 43 :

Anak yang dilahirkan diluar perkawinan hanya mempunyai hubungan perdata dengan ibunya dan keluarga ibunya.

Pasal 44 :

Pengadilan memberikan keputusan tentang sah/tidaknya anak atas permintaan pihak yang berkepentingan.

Menurut KUHPerdata anak yang dilahirkan atau dibesarkan selama perkawinan, memperoleh suami sebagai ayahnya (Pasal 250 KUHPerdata). sahnya anak yang dilahirkan sebelum hari keseratus delapan puluh (6 bulan) dari perkawinan dapat diingkari oleh suami (Pasal 251 KUHPerdata). Anak luar kawin kecuali, yang dilahirkan dari perzinahan atau sumbang. disahkan oleh

\footnotetext{
${ }^{5}$ Omar Salim, Dasar-Dasar Hukum Waris Di Indonesia, Jakarta: PT. Rineka Cipta, 2006, hlm. 90 .
} 
perkawinan yang menyusul dari ayah dan ibu mereka, bila sebelum melakukan pengakuan secara sah terhadap anak itu, apabila pengakuan terjadi dalam akta perkawinanya (Pasal 272 KUHPerdata. Terhadap anak luar kawin yang diakui agar dapat mempunyai hubungan hukum dengan orangtuanya maka ia harus diakui, Anak luar kawin yang sudah diakui dapat disahkan atau menjadi anak sah, apabila kedua orangtuanya (yang memberikannya) kemudian melangsungkan perkawinan yang sah.

Hubungan anak angkat dengan sanak saudara yang mengakuinya tidak ada hubungan darah. Oleh KUHPerdata ada kemungkinan seorang anak tidak hanya mempunyai bapak. melainkan juga tidak mempunyai ibu dalam pengertian, bahwa antara anak dengan seorang wanita yang melahirkanya itu, tidak ada hubungan hukum sama sekali tentang pemberian nafkah, warisan dan lain-lainya. Antara anak dan ibu baru ada perhubungan hukum, dimana pengakuan itu harus dilaksanakan dengan sistem tertentu, yaitu menurut pasal281 KUHPerdata dengan akta otentik sendiri (akte notaris) bila belum diadakan dalam akta kelahiran si anak atau pada waktu pelaksanaan perkawinan, dapat juga dilakukan dengan akta yang dibuat pegawai catatan sipil.

\section{Kesimpulan}

Berdasarkan dari uraian-uraian mengenai pengangkatan anak dan akibat hukumnya tersebut, maka dapat disimpulkan bahwa proses pelaksanaan pengangkatan anak menunjukan bahwa alasan sebagian besar adalah karena tidak mempunyai anak, pemohon pengangkatan anak sebagian besar adalah pasangan suami isteri yang telah lama menikah namun belum dikaruniai anak. Usia anak angkat sebagian besar berusia dibawah enam tahun dan anak tersebut dari lingkungan sendiri. Dalam kenyataan, ada beberapa orang tua angkat yang belum mengetahui.

Kalau dalam pelaksanaan pengangkatan anak itu tidak hanya diperlukan adanya suatu penyerahan anak dari orang tua kandung kepada orang tua angkat saja, namun diperlukan pula adanya pengesahan melalui penetapan Pengadilan Negeri. Juga diperlukan adanya perubahan data nama orang tua dari nama orang tua kandung berubah menjadi nama orang tua angkat dari kantor catatan Sipil Pengadilan Negeri.

\section{Daftar Pustaka}

Departemen Pendidikan Nasional, Kamus Besar Bahasa Indonesia, Jakarta, Edisi Ketiga Balai Pustaka, 2007. 
Ahmad Kamil, Fauzan, Hukum Perlindungan dan Pengangkatan Anak di Indonesia, Jakarta: 2008.

Rosnidar Sembiring, Hukum Keluarga, Jakarta: Sinar Grafika, 1992.

Omar Salim, Dasar-Dasar Hukum Waris Di Indonesia, Jakarta: Rineka Cipta, 2006.

Soedaryo Soimin, Hukum Orang dan Keluarga, Jakarta, Sinar Grafika, 1992.

Surojo Wignjodipoero, Intisari Hukum Keluarga, Bandung: Alumni, 1973.

\section{Peraturan Perundang-undang}

Kitab Undang-undang Hukum Perdata Undang-Undang Nomor 23 Tahun $2002 \quad$ Tentang Perlindungan Anak

Undang-Undang Nomor 4 Tahun1979 Tentang Kesejahteraan Anak
Peraturan Pemerintah Nomor 54 Tahun $2007 \quad$ Tentang Pelaksanaa Pengangkatan Anak. 